\title{
Values, ethics, and attitudes (IES 4) and earnings management from the viewpoint of the financial accountants at Amman Stock Exchange
}

\author{
Yaser Saleh Al frijat ${ }^{\mathrm{a}, 1}$ and Ibrahim Emair Albawwat ${ }^{\mathrm{a}}$ \\ ${ }^{a}$ Tafila Technical University, Jordan
}

\begin{abstract}
Research Question: Does the effective focus on values, ethics, and attitudes will lead financial accountants to the real management of earnings? Motivation: The authors indicated that the market needs to develop a strategic plan for ethical learning by a committee of financial and academic experts to the formulation of the basic principles in ethics and attitudes to be adopted in profit management. Idea: The objective is to discuss the importance of Professional Ethics, focusing on international education standard IES 4, and its relationship with Earnings Management, a Jordanian study. Data: The study had one group of participants that consisted of financial accountants they work with listed the companies on the Amman stock exchange (ASE) and were randomly selected. Tools: The questionnaire was analyzed using descriptive statistics, ANOVA and correlation analysis. Findings: The results of the study, indicated that the rules of accounting ethics in accordance IES4 have a significant and positive impact on earnings management (EM), whether in which in the applying the ethical behaviour, excellence pursuit, professional manner and social responsibility. Contribution: This research paper is a value-addition to the literature of professional ethics education, at the findings of this paper are expected to be of high importance about ethics value for financial accountants in the emerging economies on how to comply with IES4, to help them on leads to real management of profits.
\end{abstract}

1 Corresponding author: Department of Accounting, Business Faculty, Tafila Technical University, Jordan; tel. (+962772254305), email address yaser_frejat@yahoo.com 
Keywords: Values, ethics, and attitudes (IES4), accounting education, earnings management, financial accountants, Jordan.

\section{JEL code: M40, M41}

\section{Introduction}

Accounting ethics are strongly related to the earnings management (EM) for companies because the ethics derived from the knowledge culture received by the accountant and auditor during the academic stages is reflected in the quality of the financial statements prepared by companies. As a result of the financial challenges and disruptions faced by the companies in the global markets due to the lack of clarity and reliability in the financial reports, which leads to the prominent financial scandals of the global audit companies, Bruns and Merchant (1990) were the first researchers from "Harvard Business" who activated a "survey of the readership" on the practices of earnings management (EM).

The issue of earnings management (EM) has been and still is a major worry for the accounting profession (Elias, 2004), as many of the ethical behaviours practised in the earnings management procedures are unfavourable (Merchant \& Rockness, 1994). Grasso et al. (2009) identified several negative impacts for managing the organisation's earnings. Healy (1985) indicated that financial managers engage in manipulation of earnings management (EM), for instance, by accounting on accruals in a way that increases their rewards. Examples include: "provisioning for bad debts and delaying asset write-offs" (Roychowdhury, 2006).

Accountants face ethical challenges during their career. Brown and Trevin (2006) indicate that ethical leadership remains largely unexplored, offering researchers opportunities for discoveries and leaders with opportunities to improve their effectiveness. Shafer and Wang (2011) indicate that the ethical situation in a firm causes ethical behaviour within the employees and is unsupportive towards unethical behaviour, with the effect that employees' opinions change towards ethical acceptance for all questionable business. So, why does management smoothen their financial statements, and manipulate their earnings? Firstly, to avoid the taxation pressures facing the companies. Secondly, the desire to attract investments. Finally, due to the absence of an ethical system for financial managers and auditors. These reasons will result in a lack of credibility and clarity in the essential financial characteristics of accounting information. 
Business ethics not only reinforces academics and accountants' interest in moral practices and profit management but also supports the view that there is a shortage of ethics and moral behaviour on the part of companies and management (Karassavidou \& Glaveli, 2006). Academic staff in universities is being called to combine coverage of ethical cases in curricula (Haas, 2005; Low et al., 2008; Massey \& Van Hise, 2009).

The ethicality of earnings' management (EM) has been discussed for a long time (Lan et al., 2015). Nearly fourteen years ago, Titard et al. (2004) indicated there was a growing awareness of ethics learning in many professional accounting curricula. O'Leary (2009) indicates that ethics education for students in the accounting field is useful. Accounting education is seen as a possible therapy for the ethical crisis of the accounting profession (Jackling et al. 2007). IFAC member bodies encourage a commitment to learning and development activities that cover professional ethics to create a professional accountant to work in the public interest, for the purpose of developing an awareness and concern for impact on public; lifelong learning; providing quality; reliability, social responsibility, timeliness, and kind treatment; and a compliance for laws and directions, all of the above which support the vision that assures confidence in the positioning of markets and the economy (IFAC, 2016).

The previous studies indicated to the importance of educational ethics in the field of the accounting profession, but due to lack of studies that examined the importance of ethics, values and attitudes (IES4), in developing countries, especially Jordan. In recent years, Jordan has shed light on the essential role of education standards with the increasing number of universities, as the number of public universities 10, private 19, and two regional (Mohe.gov.jo), which provided more qualified financial accountants that contribute to the development of Jordanian business market, Which will be reflected positively on the real management of earnings to companies listed at Amman Stock Exchange. In addition, three of the Jordanian universities were ranked among the top 1,000 in the world for 2019, the Jordan University of Science and Technology ranked 651-700 at the highest level 1000 in the world, as well as the University of Jordan from 601650 and the German Jordanian University from 751 to 800 (Top Universities, 2019).

\section{Literature review and research questions}

The fundamental question is: Why this serious attention to ethics and the emphasis on it by research? Ethics is one of the most important knowledge inputs that students should learn in universities. The above question makes us 
think that there are problems in morals in the accounting profession, whether financial accountants or auditors, that in turn led to the collapse of many large international audit companies. Prior studies indicate the importance of ethics in the field of accounting education (e.g., Fisher et al., 2005; Ladewi, 2014; Low et al., 2008; Thomas, 2012; Mahdavikhou, \& Khotalou, 2012; Abdul Rahman, 2003; McPhail, 2001; Marzuki, et al., 2017; Adkins, \& Radtke, 2004; Watty, et al., 2014; David, et al., 2015). Also, previous studies focused on the role of ethics in earnings management, (e.g., Kaplan, 2001; Schipper, 1989; Bruns \& Merchant, 1990; Merchant \& Rockness, 1994; Parfet, 2000; Davis-Friday \& Frecka, 2002; Ronen \& Yaari, 2008; Dugan et al., 2016). Likewise, the importance of teaching ethical behaviour in management accounting has been highlighted (Bampton \& Cowton, 2002; Coppage \& Sriram, 1992). In addition to that, there are many studies focused on the ethics and auditor judgments (Pflugrath et al., 2007; Preuss, 1998; Jones et al., 2003; Sweeney et al., 2010). The collapse of large companies has generated massive concerns about ethics in accounting education (Young \& Annisette, 2009; Yang \& Wu, 2009). Moreover, there are other studies that support ethical reasoning abilities (McCabe et al., 1991; Rest \& Thomas, 1985). Accounting ethics is conceived to be decisive in labour markets (Bean \& Bernardi, 2007). Accordingly, our research question is:

RQ: Does the effective focus on values, ethics, and attitudes will lead financial accountants to the real management of earnings?

The previous studies provide basic accounting information on which all researchers are based in their research papers, the most important of which are: Suttipun et al. (2018) state that the purpose of this empirical paper conducted in Thailand, is to examine the technical competency levels according to the IES, and the understanding level according to the Thai Reporting Standards. The sample included 425 professional accountants working in companies. The findings showed that the five IES were ranked in terms of importance as follows: competencies, the professional's skills, the relations, analysis, ethical competency, and knowledge competency. Abidin et al. (2017), conducted a study from the stakeholders' perspective. The study indicates that commitment to ethical values has high positive effects on firms and results in better financial performance. The researchers used return on assets (ROA) and return on equity (ROE) to measure financial performance. The findings show a significant positive relationship between commitment towards ethics and financial performance.

Hess et al. (2017) employ educational experimental cases that introduced to students and professionals ethical problems faced by CPAs. The students indicate it to be an essential learning experience that led them to determine the ethical cases facing accountants whether personal or professional. Marzuki et al. (2017) state 
that the primary purpose of this study is to investigate the extent of ethics education integration in the accounting curriculum. The findings indicated that "ATD, HUDS, and PIERCE" have a positive effect on Accounting Academics. Chaplin (2017) says that this research paper is to test the impact of the use of outsourcing by Australian accounting firms on the skills of graduates from the accounting department. The study found that the external use of these resources can change 12 necessary skills for graduates.

Coram et al. (2016) state that the purpose of this paper is to examine "the importance of economic factors as well as the ethical considerations" in the managers' decision-making process. It shows that prevailing factors in the initial decision to manage the earnings is whether EM is questionable morally when dealing with the economic consequences of stakeholders rather than the selfinterests of the manager. Dugan et al. (2016) focus on the relative ethical impacts of accrual versus real earnings management. The management's interest includes how to meet the analysts' annual earnings forecasts and its impact on the future performance of the firm as well as to use ethical decision-making to assist students' treatment of the difference between the two types of EM. Lan et al. (2015), aimed at examining whether egoistic intent as a feature of EM has an influence on the assessment of the level of moral acceptability to EM. The results showed statistically significant differences in ethical acceptability that evaluations attributed to intent.

Shafer (2015) suggests and tests a model for the relationships between the accountants' perspectives about the moral climate in their companies, necessity of the awareness of ethics and social responsibility in the company, and profit management decisions. The results indicated regulatory effort aimed at moral support climate and confirmed that the ethical importance and social responsibility in the organization can minimize the spread of earnings management manipulation. Ardelean (2013) finds a series of financial scandals that result in a deep erosion of clients' confidence regarding their trust in the audit process. This growing concern led to this paper and brought out how the perceived morals of the auditors have affected the confidence of large-scale clients. Also, the growing interest to ethics is due to increased care for quality.

Liu et al. (2012) investigates the views of academic accounting staff related to the teaching ethics by investigating the teaching methods of medicine and law. The study concludes that ethics education in accounting shows deficiencies regarding the content and the formal training are less systematic and there is less use of the partnership compared to moral education in medicine and law. Johnson et al. (2012) examine how positive organizational results affect managerial responses to employees behaviour in EM, and the researchers gave their attention to the question: "Do the ends of positive organizational consequences justify the means 
of earnings management"? Klimek \& Wenell (2011) discuss the ethical logic capabilities of accounting students compared to the moral logic capabilities of accounting students who had ethics discussions incorporated into accounting courses rather than the required curriculum. Findings indicate that students who took an ethics course in accounting before they graduated from the university seemed to have higher moral thinking abilities.

Shafer \& Wang (2011) investigate the implications of Chinese accountants' perspectives on ethical stances towards EM. The results found that views of a robust institution serving the public attention significantly reduced the readiness of professional accountants to ignore EM. Greenfield et al. (2008) study the influence of ethical ideology and the degree of professional pledge for persons towards EM decisions, to check if there are personal interests that influence ethical trends or professional pledge of an opportunity to manage earnings. Blanthorne et al. (2007) review the results of a comprehensive survey of the views and practices of the accounting divisions on ethical teaching. The findings of the survey emphasized the inclusion of professional ethical education in the accounting curriculums in the universities so that accountants are aware of the vital importance of morals to achieve the requirements of the profession.

Pflugrath et al. (2007) examin the existence of a morals code and its impact on "the quality of auditors' judgments," in the context of the new "International Standard on Quality Controls 1" (ISQC1). The study proved that the existence of ethics code has a positive impact on the quality of issued judgments, just by professional accountants, without students. Dellaportas et al. (2006) indicate implications of education ethics from an "IES 4", and the challenges arising from an "international professional accounting body" about ethics education. The study provided the most important considerations that need to be treated to maintain continuity in the success of the IES4 application. Roychowdhury (2006) examines how financial managers manipulate the real operational activities of the entity to evade yearly losses. The evidence indicates that decreased prices temporarily increase sales and increase in production causes a decrease in the sales cost and minimize discretionary expenditures. Al-Hayale and Lan (2005) conduct a comparative study between the positions of financial managers and external auditors about the widespread practices in profit management in Jordan. "Mann-Whitney U" tests present that the external auditors mostly look at earnings management pursuits as below ethical than the financial managers. Elias (2004) conducts a study inclusive on 583 "certified public accountants (CPAs)" in academia, public accounting, and industry to set if there is a link between ethical attitudes for corporate and views of earnings management.

Bampton and Cowton (2002) explain the extent to which ethical matters are included in the education of managerial accounting curriculum in universities. The 
main result is that most of the academic staff in the managerial accounting curriculum do not include ethics. McPhail (2001) explores how to introduce the subject in accounting education through the teaching of business ethics to make suggestions for humanitarian accountability and to develop a sense of moral commitment to other persons. Preuss (1998), discusses methods to support ethics amongst auditors on the basis that ethics behaviour codes are very necessary. Merchant and Rockness (1994) investigate the Practices of earnings management, and apply an ethical perspective and whether transactions of earnings management are the right thing to do. Hand (1989) indicates that the corporations conduct debt-equity swaps to smooth recorded profits thus mask fluctuations in real profits patterns. Based on the above, and to this end, the paper proposed the following research questions, which allow the exploratory of the relationship between international education standards and earnings management is formulated as:

RQ1: Does the effective focus on ethical behaviour will lead financial accountants to the real management of earnings?

RQ2: Does the effective focus on excellence pursuit will lead financial accountants to the real management of earnings?

RQ3: Does the effective focus on a professional manner and social responsibility will lead financial accountants to the real management of earnings?

The findings of this paper are expected to be of high importance about ethics knowledge for financial accountants in companies listed in the Amman Stock Exchange on how to comply with IES 4, to help them on leads to real management of profits. Thus, other sectors in outside ASE are expected to benefit from the findings of this study.

\section{Earnings management and ethics}

As a result of awareness and attention from global financial committees, government agencies, investors, and shareholders the trend of continuous calls from all financial sectors to deepen the concepts of ethics in the academic institutions to create qualified students with high ethics to serve the labour markets began; they would have to work in the future as accountants and auditors.

Levitt (1998) indicated that earnings management that has become a "game of nods and winks" among corporate financial managers, auditors and analysts. The practice of earnings management is a purposeful intrusion in the external reporting 
process with the purpose of the acquisition of some private income (Schipper, 1989). The unfavourable intentions of earnings management appears to assure the SEC's call to prevent this practice (Elias, 2002). The earnings management masks the right financial status for business entities also hides pertinent financial information that investors must see (Loomis, 1999). Ronen and Yaari (2008) categorize earnings management operations as "black," "white," or "grey" based on their clarity and aimed purpose. Fischer and Rosenzweig (1995) indicate that earnings management is the behaviour of corporate financial managers to rise (reduce) currently reported profits of an entity without a corresponding rise (reduce) in long-time economic profitability. Earnings management is selecting an accounting treatment that is either opportunistic for the purpose of maximizing the utility of management or economic competence (Ronen \& Yaari, 2008).

In general, the increase in business education has led to a high worth of moral instruction to accounting students in the last 30 years (Madison \& Schmidt, 2006). What makes morality necessary is that it creates universal principles regarding what is correct and what is incorrect with human behaviour (Tutar et al. 2011). McPeak et al. (2012) provide assurance for the need for "global convergence" in the field of accounting education across countries by promoting international accounting education. The concept of moral regulatory culture is generally similar to the moral climate since both are measures of the public ethical environment within the institution (Shafer, \& Wang, 2011). Trevino et al. (1999) "developed a conception of ethical culture that is less theoretical than the ethical climate construct." Victor \& Cullen (1988) "defined the organizational ethical climate as the prevailing perceptions among employees of ethical practices." Accounting ethics are seen as critical to the development of labour markets (Bean \& Bernardi, 2007).

In 2003, "The International Federation of Accountants (IFAC) issued a set of international education standards (IES), focused on several targets, most notably Standard (IES 4), which refers to professional ethics, values and attitudes to prepare candidates for membership of the (IFAC) membership to act as professional accountants. The International Accounting Standards Boards (IASB) plays an active role in moving towards international rapprochement in the field of accounting education (Sugahara \& Watty, 2016). The ethical professional values standard contributes several goals which are most important to the protection of public interest, enhances business quality for accountants and also the trustworthiness of the accounting profession (IFAC, 2016).

The objective of this IES4 is to establish the professional values, ethics and attitudes that "aspiring professional accountants" need to develop and demonstrate by the end of IPD to perform the role of a professional accountant (IFAC, 2016). The professional standard IES4 describes "values, ethics and attitudes of 
professional accountants" that must be obtained within the accounting education program leading to qualification (IFAC, 2016). The ethical requirements in professional accounting education include five major principles of professional ethics: "integrity; objectivity; professional competence and due care; confidentiality; and professional behaviour" (IFAC, 2016).

\section{Methodology}

\subsection{Study method}

The study discusses an active perceived emphasis on value, ethics and attitudes (IES 4) and its importance in earnings management. The study was conducted using financial accountants at the Amman Stock Exchange. All sample individuals were from industrial, service, bank and insurance sectors. The value of listing financial accountants is to reaffirm that they have the responsibility for preparing corporate financial reports. The more the financial accountant's ethics is sustained, the more the reliability of the corporate financial reports.

The research instrument includes personal information of the respondents to the questionnaire and it may influence earnings management. Stead et al. (1990), and Ho et al. (2015) determined that gender and age may influence ethical decisions. Also, Thorne et al. (2003) worked to determine the length of work experience as an important factor in the study. Clayton and Staden (2015) incited that qualifications have some regard in the literature review.

The other section was designed to gather the respondent's opinions about questionnaire questions and consisted of independent variables (Ethical behaviour, the pursuit of excellence and professional manner and social responsibility). Financial accountants that were surveyed to collect data in the Amman Stock Exchange consisted of 185 financial accountants. The sample of 154 usable responses was received. Response rates were eighty-three per cent and they were assured of confidentiality. The questionnaire was analyzed using descriptive statistics, ANOVA and correlation analysis.

The questionnaire was tested by several Arbitrators to review it for substance and format; all questionnaire questions are derived from the content of international educational standard 4. Details about personal information for respondents is as follows: 
Values, ethics, and attitudes (IES 4) and earnings management from the viewpoint of the financial accountants at Amman Stock Exchange

Table 1. Personal background of respondents

\begin{tabular}{|c|c|c|}
\hline Demographic variable & $\begin{array}{l}\text { Frequency } \\
\text { (Percentage) }\end{array}$ & $\begin{array}{l}\text { The respondent has an agree } \\
(\mathbf{8 0 \%})\end{array}$ \\
\hline \multicolumn{3}{|l|}{ Gender } \\
\hline Male & $146(95 \%)$ & $117(76 \%)$ \\
\hline Female & $8(5 \%)$ & $5(3.3 \%)$ \\
\hline Total & 154 & 122 \\
\hline \multicolumn{3}{|l|}{ Age } \\
\hline Under 35 years & $61(40 \%)$ & $49(32 \%)$ \\
\hline $35-55$ years & $76(49 \%)$ & $61(40 \%)$ \\
\hline Above 55 years & $17(11 \%)$ & $12(8 \%)$ \\
\hline Total & 154 & 122 \\
\hline \multicolumn{3}{|l|}{ Qualification } \\
\hline $\mathrm{PhD}$ & $12(8 \%)$ & $9(6 \%)$ \\
\hline Master & $41(27 \%)$ & $32(21 \%)$ \\
\hline $\begin{array}{l}\text { Bachelor } \\
\text { diploma degree }\end{array}$ & $\begin{array}{c}101(65 \%) \\
0\end{array}$ & $81(53 \%)$ \\
\hline Total & 154 & 122 \\
\hline \multicolumn{3}{|l|}{ Specialization Major } \\
\hline Accounting & $85(55 \%)$ & $74(48 \%)$ \\
\hline Business & $34(22 \%)$ & $25(17 \%)$ \\
\hline Economics & $16(10 \%)$ & $10(6.5 \%)$ \\
\hline Banking and Financial Sciences & $19(13 \%)$ & $13(8.5 \%)$ \\
\hline Total & 154 & 122 \\
\hline \multicolumn{3}{|l|}{ Years of Experience } \\
\hline Below ten years & $33(21.5 \%)$ & $23(15 \%)$ \\
\hline 10 - Below 20 years & $83(54 \%)$ & $72(47 \%)$ \\
\hline 20 - Below 30 years & $34(22 \%)$ & $24(16 \%)$ \\
\hline Above 30 years & $4(2.5 \%)$ & $3(2 \%)$ \\
\hline Total & 154 & 122 \\
\hline \multicolumn{3}{|l|}{ Sectors } \\
\hline Industrial & $51(33 \%)$ & $43(28 \%)$ \\
\hline Service & $22(14 \%)$ & $16(11 \%)$ \\
\hline Bank & $45(29 \%)$ & $34(22 \%)$ \\
\hline Insurance & $36(24 \%)$ & $29(19 \%)$ \\
\hline Total & 154 & 122 \\
\hline \multicolumn{3}{|l|}{ professional certificate } \\
\hline International CPA, CMA,CIA & $34(22 \%)$ & $28(18 \%)$ \\
\hline National JCPA & $77(50 \%)$ & $63(41 \%)$ \\
\hline None of the above & $43(28 \%)$ & $31(21 \%)$ \\
\hline Total & $154(\% 100)$ & $122(80 \%)$ \\
\hline
\end{tabular}

Respondents' analysis was preceded as shown in the above Table 1. Results indicate that the gender of the respondents to the questionnaire was mostly male, the reason behind that, the profession is an association with males more than female in the Jordanian market (Abdullatif, 2013). The majority of the respondents 
have a bachelor's degree 83 ( 54 per cent), and 53 ( 35 per cent) of the respondents have $\mathrm{PhD}$ and master degree, and that they are highly specialization in the field of accounting, and they have extensive knowledge in accounting issues. Also, most of the respondents were aged between 35 and 55 years, 83 (54 per cent) of the respondents had below 20 years of working experience. $28(18 \%)$ of the financial accountants surveyed had international certificates, 63(41\%) they are had locally Jordanian certificates, and 31(21\%) without international and local certificates.

\subsection{Descriptive statistics}

The independent variables were tested through the following questions:

The first research question

RQ1: Does the effective focus on ethical behaviour will lead financial accountants to the real management of earnings?

Table 2. ethical behavior

\begin{tabular}{|c|c|c|c|c|c|}
\hline \multirow[b]{2}{*}{ Items } & \multirow[b]{2}{*}{ Mean } & \multirow[b]{2}{*}{$\begin{array}{l}\text { Std. } \\
\text { Dev. }\end{array}$} & \multicolumn{3}{|c|}{$\begin{array}{c}\text { The respondents' } \\
\text { perception }\end{array}$} \\
\hline & & & $\underset{\%}{\text { Agree }}$ & $\begin{array}{c}\text { Neither } \\
\%\end{array}$ & disagree \% \\
\hline Integrity in professional relations & 4.116 & 0.892 & 82.3 & 4.3 & 13.4 \\
\hline Honesty, and justice while doing duty & 3.935 & 1.191 & 78.7 & 6.1 & 15.2 \\
\hline Fairness and intellectual honesty & 3.714 & 1.181 & 74.3 & 7.2 & 18.5 \\
\hline Avoid mistakes and differences in opinion & 3.772 & 1.301 & 75.5 & 2.1 & 22.4 \\
\hline $\begin{array}{l}\text { Compliance with the text of the technical } \\
\text { standards, } \\
\text { and the application of laws, regulations }\end{array}$ & 3.844 & 1.258 & 76.9 & 3.6 & 19.5 \\
\hline $\begin{array}{l}\text { To maintain the confidentiality of financial } \\
\text { information and not to disclose it unless } \\
\text { there is a legal obligation }\end{array}$ & 3.844 & 1.273 & 76.9 & 8.5 & 14.6 \\
\hline \multirow{2}{*}{$\begin{array}{l}\text { Avoiding any work that distracts from the } \\
\text { profession } \\
\text { that he practices by keeping away from } \\
\text { cheating and embezzlement of financial } \\
\text { reports }\end{array}$} & 4.220 & 1.133 & 84.4 & 1.6 & 14 \\
\hline & 3.921 & 0.474 & 78.4 & 4.8 & 16.8 \\
\hline
\end{tabular}

Table 2, presents a mean value of 3.921 , std deviation of 0.474 , and the respondents have an agreement for $78.4 \%$. The results as shown in the above test revealed a significant positive relationship between commitment to ethical behavior and earnings management. This indicates that the moral behaviour of the integrity, honesty, justice and compliance with the text of the technical standards, avoiding any work that distracts from the profession that one practice by keeping away from cheating and embezzlement of financial reports have an active contribution to the real management of profits. 
Values, ethics, and attitudes (IES 4) and earnings management from the viewpoint of the financial accountants at Amman Stock Exchange

The second research question

RQ2: Does the effective focus on excellence pursuit will lead financial accountants to the real management of earnings?

Table 3. Excellence pursuit

\begin{tabular}{|c|c|c|c|c|c|}
\hline \multirow[b]{2}{*}{ Items } & \multirow[b]{2}{*}{ Mean } & \multirow[b]{2}{*}{$\begin{array}{l}\text { Std. } \\
\text { Dev. }\end{array}$} & \multicolumn{3}{|c|}{$\begin{array}{c}\begin{array}{c}\text { The respondents' } \\
\text { perception }\end{array} \\
\end{array}$} \\
\hline & & & $\underset{\%}{\text { Agree }}$ & $\begin{array}{c}\text { Neither } \\
\%\end{array}$ & $\begin{array}{c}\text { Disagree } \\
\%\end{array}$ \\
\hline $\begin{array}{l}\text { Continuing commitment and lifelong } \\
\text { learning }\end{array}$ & 3.811 & 0.891 & 76.2 & 8.3 & 15.5 \\
\hline $\begin{array}{l}\text { Maintain an appropriate level of merit } \\
\text { and professionalism by following up on } \\
\text { developments } \\
\text { in financial and administrative knowledge } \\
\text { fields }\end{array}$ & 3.785 & 0.907 & 75.7 & 2.1 & 22.2 \\
\hline $\begin{array}{l}\text { Updating and developing the use of software } \\
\text { to increase the efficiency of financial } \\
\text { management }\end{array}$ & 3.701 & 0.950 & 74.03 & 5.4 & 20.57 \\
\hline $\begin{array}{l}\text { Continuing follow-up of all training courses } \\
\text { that are } \\
\text { of interest to financial and administrative } \\
\text { activity }\end{array}$ & 3.532 & 1.155 & 70.7 & 3.4 & 25.9 \\
\hline $\begin{array}{l}\text { Continuous development in improving the } \\
\text { performance level of professional work }\end{array}$ & 3.798 & 1.031 & 76 & 12.3 & 11.7 \\
\hline $\begin{array}{l}\text { Continuing support, for ethics and behaviour } \\
\text { through } \\
\text { the educational curriculum in universities }\end{array}$ & 3.798 & 1.110 & 76 & 9.1 & 14.9 \\
\hline \multirow{2}{*}{$\begin{array}{l}\text { Continuity in improving the financial } \\
\text { performance of } \\
\text { the company through the suggestions that } \\
\text { contribute to increasing profits }\end{array}$} & 3.883 & 0.983 & 78.7 & 1.3 & 20 \\
\hline & 3.758 & 0.430 & 75.3 & 5.99 & 18.68 \\
\hline
\end{tabular}

Table 3 presents a mean value of 3.758 , std deviation of 0.430 ; and $75.3 \%$ of financial accountants have indicated the importance of continuing lifelong learning. The results as shown in the above test revealed a significant positive relationship between commitment to excellence pursuit and earnings management.

The third research question

RQ3: Does the effective focus on a professional manner and social responsibility will lead financial accountants to the real management of earnings. 
Table 4. Professional manner and social responsibility

\begin{tabular}{|c|c|c|c|c|c|}
\hline Items & Mean & $\begin{array}{l}\text { Std. } \\
\text { D. }\end{array}$ & $\underset{\%}{\text { Agree }}$ & $\begin{array}{l}\text { Neither } \\
\%\end{array}$ & $\begin{array}{c}\text { Disagreed } \\
\%\end{array}$ \\
\hline $\begin{array}{l}\text { Full disclosure and transparency of appropriate } \\
\text { financial information that requires presentation }\end{array}$ & 4.137 & 0.903 & 82.75 & 4.3 & 12.95 \\
\hline $\begin{array}{l}\text { Courteous and respectful in dealing with } \\
\text { stakeholders and customers }\end{array}$ & 3.487 & 1.030 & 70 & 3.8 & 26.2 \\
\hline $\begin{array}{l}\text { Perform duties by applicable professional } \\
\text { regulations and laws }\end{array}$ & 3.805 & 0.686 & 76.1 & 4.9 & 19 \\
\hline Observance for timing in work & 3.629 & 1.131 & 72.6 & 3.5 & 23.9 \\
\hline $\begin{array}{l}\text { Attention to the general interest of the } \\
\text { company }\end{array}$ & 4.013 & 0.855 & 80.3 & 1.3 & 18.4 \\
\hline \multirow{2}{*}{$\begin{array}{l}\text { Control on the financial problems that facing } \\
\text { the company, } \\
\text { and work to find solutions for its (bankruptcy, } \\
\text { financial failure, a decrease in sales volume, } \\
\text { and control of expenses) }\end{array}$} & 3.818 & 0.874 & 76.4 & 2.5 & 21.1 \\
\hline & 3.810 & 0.439 & 76.36 & 3.38 & 20.26 \\
\hline
\end{tabular}

Table 4 presents a mean value of 3.810, and std deviation of 0.439 ; also, a high percentage 76.36 of financial accountants have indicated the importance to Professional manner and Social responsibility. The results as shown in the above test revealed a significant positive relationship between commitment to the professional manner and social responsibility and earnings management real. This means that the Full disclosure and transparency of appropriate financial information, Perform duties by applicable professional regulations and laws, Attention to the general interest of the company, also to control on the financial problems that facing the company, and work to find solutions for its, have an active contribution to the real management of profits.

\subsection{ANOVA and correlation analysis}

Table 5. ANOVA Test

\begin{tabular}{|c|c|c|c|c|}
\hline $\begin{array}{c}\text { Sum of } \\
\text { Squares }\end{array}$ & Df & Mean Square & $\mathbf{F}$ & Sig. \\
\hline 15.938 & 4 & 3.984 & 337.430 & $0.000^{\mathrm{b}}$ \\
\hline 1.759 & 149 & 0.012 & & \\
\hline 17.697 & 153 & & & \\
\hline
\end{tabular}

Table 5 shows that the model is significant with $\mathrm{F}$ value of (337.430). As the amount of significance is 0.000 less than 0.05 , the result is that the relationship between professional ethics and real earnings management is statistically significant at a level below 0.05 . 
Values, ethics, and attitudes (IES 4) and earnings management from the viewpoint of the financial accountants at Amman Stock Exchange

Table 6. Correlation coefficient

\begin{tabular}{lcccc}
\hline Earningsma & Coef. & Std. Err. & T & P> t \\
\hline RQ1 & $2.02 \mathrm{e}+07$ & $1.20 \mathrm{e}+07$ & 1.69 & 0.094 \\
RQ2 & 3108120 & 4667991 & 0.67 & 0.507 \\
RQ3 & 5343283 & 3915230 & 1.36 & 0.174 \\
Cons & $3.00 \mathrm{e}+07$ & $2.18 \mathrm{e}+07$ & 1.37 & 0.172 \\
\hline
\end{tabular}

As per the correlation coefficient findings presented in Table 6 there was a significant (at 5\% level) positive association between earnings management as the dependent variable and all the independent variables, RQ1 ethical behavior, $r$ equal 0.094, RQ2 pursuit of excellence and Professional manner $r$ equal 0.507 and RQ3 Social responsibility $\mathrm{r}$ equal. 0.174 .

What is the relation between the education ethics standards and the real management of earnings?

when $\mathrm{E}[\mathrm{Yi} \mid \mathrm{X} 1 \mathrm{i}]=\beta 0+\beta 1 \mathrm{X} 1 \mathrm{i}$

Table 7. Correlation analysis

\begin{tabular}{ccccc}
\hline RQ & EM & RQ1 & RQ2 & RQ3 \\
\hline EM & 1.000 & & & \\
RQ1 & 0.483 & 1.000 & & \\
RQ2 & 0.612 & 0.653 & 1.000 & \\
RQ3 & 0.528 & 0.419 & 0.595 & 1.000 \\
\hline
\end{tabular}

Table 7 indicates no multi correlation problem between independent variables since the high correlation value 0.653 means this value was got from those studies which suggested the beginning of the multi correlation problem with 70 per cent.

\section{Conclusion}

The persistence of financial scandals in international companies and related financial organizations has galvanized more attention in and request for professional ethics. Business faculties and accounting education programs in universities worldwide, contribute to preparing the most ethical and competent future professional accountants. The findings are very important in practical life especially to financial accountants employed in listed corporations at the Amman stock exchange. The sample of accountants assures that professional values, ethics, and attitudes more closely correlate with earnings management.

It is expected that the research results will contribute to the importance for ethics, values, and attitude to financial accountants in earnings management so that they avoid the decorating of financial statements and be of subsequent interest to researchers in the future. Also, it is expected that the perception levels for financial 
accountants in improvement and development for each of the ethical behaviour, excellence pursuit, professional manner and social responsibility.

Results show that there are strong perceptions and essential implications on active perceived emphasis for value, ethics and attitudes, whether in which in the applying integrity in professional relations, honesty, and justice while doing duty, fairness and intellectual honesty, avoiding mistakes and differences in opinion, the application of laws, regulations and confidentiality of financial information and not to disclose. Also, excellence pursuit maintain an appropriate level of merit and professionalism by following up on developments in financial and administrative knowledge fields, updating and developing the use of software and continuously improving the performance levels of professional work. Also, full disclosure and transparency of appropriate financial information requires presentation, courteousness and respectfulness in dealing with stakeholders and customers, and performing of duties by applicable professional regulations and laws, attention to the general interest of the company, and attention to the public interest of the company. There are various studies that supported these results (e.g., Suttipun, et al. 2018; Marzuki et al. 2017; Dugan, et al. 2016; Shafer, 2015; Klimek, \& Wenell 2011; Dellaportas et al. 2006), also (e.g., Abidin et al., 2017; Johnson et al. 2012; McPhail 2001).

The findings of this paper provide insights for the International Accounting Education Standards Boards (about the necessity to activate ethics, values and attitudes) in the process of managing profits towards companies. Further, we recommend the development of a strategy that targets financial accountants to the formulation of principles to be adopted in profit management. Also the demand from universities, specifically, accounting departments to work towards improving the competencies of a graduate in accounting program, and develop mandatory training programs for qualified accountants to enter the labour market, encourage compliance with the text of the professional accounting standards, support the confidentiality of financial information and not to disclose, keep away from cheating and embezzlement of financial reports, ensure integrity in professional relations, honesty and justice while doing duty, and avoid mistakes and differences in opinion.

\section{References}

Abdul Rahman, A.R. (2003) "Ethics in accounting education: contribution of the Islamic principles of maslaehah", IUUM Journal Economics and Management, vol. 11, no. 1: 2-8 
Abdullatif, M. (2013) "Fraud risk factors and audit programme modifications: evidence from Jordan", Australasian Accounting, Business and Finance Journal, vol. 7, no.1: 58-78

Abidin, A.F.Z., Hashim, H.A., \& Ariff, A. M. (2017) "Ethical commitments and financial performance: Evidence from publicly listed companies in Malaysia", Asian Academy of Management Journal, vol. 22, no. 2: 53-95

Adkins, N. \& Radtke, R. (2004) 'Students' and faculty members' perceptions of the importance of business ethics and accounting ethics education: is there an expectations gap?", Journal of Business Ethics, vol. 51, no. 3: 279-300

Al-Hayale, T., \& Lan, G. (2005) "The ethicalness of earnings management in the Middle East: a survey of managers and auditors in Jordanian companies", International Journal of Accounting, Auditing and Performance Evaluation, vol. 2, no. 24: 399-413.

Ardelean, A. (2013) "Auditors' ethics and their impact on public trust", Lumen International Conference Logos Universality Mentality Education Novelty (LUMEN 2013), Social and Humanistic Sciences. vol. xx, no. 92 (2013) $55-60$

Bampton, R. \& Cowton, C.J. (2002) "The teaching of ethics in management accounting: progress and prospects", Business Ethics: A European Review, vol. 11, no. 1: 52-61

Bean, D., \& Bernardi. R. (2007) "A proposed structure for an accounting ethics course", Journal of Business Ethics Education, vol. 4, no. 1: 1-28

Blanthorne, C., Kovar, S. \& Fisher, D. (2007) “Accounting educators' opinions about ethics in the curriculum: an extensive view", Issues in Accounting Education, vol. 22, no. 3: 355-390

Brown, M., \& Trevino. L. (2006) "Ethical leadership: A review and future directions", The Leadership Quarterly, vol. 17, no. 6: 595-616

Bruns, W., \& Merchant. K. (1990) "The dangerous morality of managing earnings", Management Accounting, vol. 72, no. 2: 22-25

Chaplin, S. (2017) "Accounting education and the prerequisite skills of accounting graduates: are accounting firms' moving the boundaries?", Australian Accounting Review, vol. 8, no. 27: 61-70

Clayton, M. B., \& Van Staden, J. C. (2015) "The impact of social influence pressure on the ethical decision making of professional accountants: Australian and New Zealand Evidence", Australian Accounting Review, vol. 25, no. 75: 372-388

Coppage, R., E., \& Sriram, R. (1992) "Ethical issues and the current code of ethics for management accountants-are they compatible?", Business \& Professional Ethics Journal, vol. 11, no. 3/4 (Fall-Winter, 1992): 165-178

Coram, P., Frederickson, J., R. \& Pinnuck, M. (2016) "Earnings management: the role of economics and ethics on managers' decision making" (November 12, 2016). Available at SSRN: https://ssrn.com/abstract=2868350 
David J. Burns, James A. \& Tackett Fran, W. (2015) "The effectiveness of instruction in accounting ethics education: another look", in Jeffrey, C. (ed.) Research on Professional Responsibility and Ethics in Accounting, vol. 19: $149-180$

Davis-Friday, P., \& Frecka. T. (2002) "What managers should know about earnings management: Its prevalence, legality, ethicality, and does it work?", Review of Accounting and Finance, vol. 1, no. 1: 57-71.

Dellaportas, S., Leung, P., Cooper, B. J. \& Jackling, B. (2006) "IES 4 - Ethics education revisited", Australian Accounting Review, vol. 16, no. 1: 4-12

Dugan, M. T., Knox III, Peter S.; \& Taylor, G. (2016) "Ethical Issues Related to Earnings Managements: An Instructional Case", Journal of the International Academy for Case Studies, vol. 22, no. 3: 84-89

Elias, R. Z. (2004) "The impact of corporate ethical values on perceptions of earnings management", Managerial Auditing Journal, vol. 19, no. 1: 84-98

Elias, R. Z. (2002) "Determinants of earnings management ethics among accountants", Journal of Business Ethics, vol. 40, no. 1: 33-45

Fisher, D.G., Blanthorne, C. \& Kovar, S.E. (2005) "Accounting educators opinions about ethics in the curriculum: a profile", Available at: www.aaahq.org/abo/Papers/FisherBlanthorneKovar2005.pdf, 1-37.

Fischer, M. \& Rosenzweig, K. (1995) "Attitudes of students and accounting practitioners concerning the ethical acceptability of earnings management", Journal of Business Ethics, vol. 14, no. xx: 33-44

Grasso, L., Tilley, P. \& White. R. (2009) "The ethics of earnings management: Perceptions after Sarbanes-Oxley", Management Accounting Quarterly, vol. 11, no. 1: 45-69

Greenfield, A. C., Norman, C. S., \& Wier, B. (2008) "The effect of ethical orientation and professional commitment to earnings management behavior", Journal of Business Ethics, vol. 83: 419-434

Haas, A. (2005) "Now is the time for ethics in education", The CPA Journal, vol. 75, no. 6: 66-68

Hand, J.R.M. (1989) "Did firms undertake debt-equity swaps for an accounting paper profit or true financial gain? ", The Accounting Review, vol. 64: $587-623$

Healy, P. M. (1985) "Effect of bonus schemes on accounting decisions", Journal of Accounting and Economics, vol. 7, no. xx: 85-107

Healy, P. M., \& Whalen, J. M. (1999) "A review of the earnings management literature and its implications for standard setting", Accounting Horizons, vol. 12, 365-384

Hess, J. D., Haney, H. M., \& MacPhail S. C. (2017) "What You Do Know Can Hurt You: An Instructional Case Requiring Application of Professional Standards to an Ethical Dilemma Facing an Auditor and Tax Preparer", Current Issues in Auditing, vol. 11, no. 1: 11-19

Ho, S.S.M., Li, A.Y., Tam, K. \& Zhang, F. (2015) "CEO Gender, Ethical Leadership, and Accounting Conservatism", Journal of Business Ethics, vol. 127: $351-370$ 
IFAC (2016) "IES 4, initial professional development - professional values, ethics and attitudes", International Accounting Education Standards Board, New York, NY.

Jackling, B., Cooper, B. J., Leung P., \& Dellaportas, S. (2007) "Professional accounting bodies' perceptions of ethical issues, causes of ethical failure and ethics education," Managerial Auditing Journal, vol. 22, No. 9: 928-944

Johnson, N. E., Fleischman, M. G., Valentine, S., \& Walker, K. B. (2012) "Managers' ethical evaluations of earnings management and its consequences", Contemporary Accounting Research. vol. 29, no. 3 (Fall 2012): 910-927

Jones, J., Massey, D.W. \& Thorne, L. (2003) “Auditors' ethical reasoning: insights from past research and implications for the future", Journal of Accounting Literature, vol. xx, no. 22: 45-103

Kaplan, S. (2001) "Ethically related judgments by observers of earnings management", Journal of Business Ethics, vol. 32, no. 4: 285-298

Karassavidou, E., \& Glaveli, N. (2006) "Towards the ethical or the unethical side? An explorative research of Greek business students' attitudes", International Journal of Educational Management, vol. 20, no. 5: 348-364

Klimek, J., \& Wenell, K. (2011) "Ethics in accounting: an indispensable course?", Academy of Educational Leadership Journal, vol. 15, no.4

Ladewi, Y. (2014) "The role of Islam values (ethics) in accounting practice and impact of accounting information quality: A library study", International Journal of Economics, Commerce, and Management, vol. 2, no. 12: 1-12

Lan, G., Gowing, M., \& Al-Hayale, T. (2015) "The role of intent on accounting students' ethical attitudes towards earnings management", Journal Academic Ethics, vol. 13:345-362

Levitt, A. (1998) "The numbers game", The CPA Journal, vol. 68, no. xx: 14-19.

Liu, C., J. Yao, J., L., \& Hu, N. (2012) "Improving ethics education in accounting: lessons from medicine and law", Issues in Accounting Education, vol. 27, no. 3: 671-690

Loomis, C.J. (1999) "Lies, damned lies, and managed earnings", Fortune, vol. 140, no. 2 August: 74-92

Low, M., Davey, H., \& Hooper. K. (2008) "Accounting scandals, ethical dilemmas, and educational challenges", Critical Perspectives on Accounting, vol. 19, no. 2: $222-254$

Madison, R. L., \& Schmidt, J. (2006) "Survey of time devoted to ethics in accountancy programs in North American colleges and universities", Issues in Accounting Education, vol. 21, no. 2: 99-109

Mahdavikhou, M., \& Khotalou, M. (2012) "New approach to teaching ethics in accounting "introducing Islamic ethics into accounting education", Procedia-Social and Behavioral Sciences. vol. 46, no. xx: 1318-1322

Marzuki, M., Subramaniam, N., Cooper, J. B., \& Dellaportas, S. (2017) “Accounting academics' teaching self-efficacy and ethics integration in accounting 
courses A Malaysian study", Asian Review of Accounting, vol. 25, no. 1: $148-170$

Massey, D. W., \& Van Hise. J. (2009) "Walking the walk: Integrating lessons from multiple perspectives in the development of an accounting ethics course", Issues in Accounting Education, vol. 24, no. 4: 481-510

McCabe, D. L. Dukerich, J. M. \& Dutton. J. E. (1991) "Context, values, and moral dilemmas: Comparing the choices of business and law school students", Journal of Business Ethics, vol. xx, no.10: 951-960

McPeak, D., Pincus, K.V. \& Sundem, G.L. (2012) "The International Accounting Education Standards Board influencing global accounting education," Issues in Accounting Education, vol. 27, no. 3: 743-750

McPhail, K. (2001) "The other objective of ethics education: Re-humanising the accounting profession: A study of ethics education in law, engineering, medicine, and accountancy", Journal of Business Ethics, vol. 34, no. (3-4): 279-98

Merchant, K., \& Rockness. J. (1994) "The ethics of managing earnings: An empirical investigation", Journal of Accounting and Public Policy, vol. 13, no. $1: 79-94$

Parfet, W. (2000) “Accounting subjectivity and earnings management: A preparer perspective", Accounting Horizons, vol. 14, no 4: 481-88

Pflugrath, G. Martinov-Bennie, N., \& Chen, L. (2007) "The impact of codes of ethics and experience on auditor judgments", Managerial Auditing Journal, vol. 22, no. 6: 566-589

Preuss, L. (1998) "On ethical theory in auditing”, Managerial Auditing Journal, vol. 13, no. 9: 500-508

Rest, J. R., \& Thoma. S, J. (1985) "Relation of moral judgment development to formal education", Developmental Psychologist, vol. 21, no. 4: 709-714

Ronen, J., \& Yaari. V. (2008) Earnings management: Emerging insights in theory, practice, and research, New York: Springer.

Roychowdhury, S. (2006) "Earnings management through real activities manipulation", Journal of Accounting and Economics, vol. 42, no. 3: 335-370

Schipper, K. (1989) "Commentary on earnings management”, Accounting Horizons. vol. 3, no. 4: 91-102

Shafer, W. E. (2015) "Ethical climate, social responsibility, and earnings management", Journal of Business Ethics, vol. 126, no. 1:43-60

Shafer, W. E., \& Wang, Z. (2011) "Effects of ethical context and Machiavellianism on attitudes toward earnings management in China”, Managerial Auditing Journal, vol. 26, no. 5: 372-392

Sugahara, S., \& Watty, K. (2016) “Global convergence of accounting education: An exploratory study of the perceptions of accounting academics in Australia and Japan”, Asian Review of Accounting, vol. 24, no. 3: 254-273 
Suttipun, M., Sattayarak, O. A., Duangpanya, P., \& Runglertkrengkrai, S. (2018) "Relationship between competency as per the international education standards for accounting professionals and the awareness and understanding of the Thai financial reporting standards for small and medium-sized enterprises: A case study accounting professionals in Thailand's southern region", Kasetsart Journal of Social Sciences

Stead, W.E., Worrell, D.L. \& Stead, J.G. (1990) "An integrative model for understanding and managing ethical behavior in business organizations", Journal of Business Ethics, vol. 9: 233-42

Sweeney, B., Arnold, D. \& Pierce, B. (2010) "The impact of perceived ethical culture of the firm and demographic variables on auditors' ethical evaluation and intention to act decisions", Journal of Business Ethics, vol. 93, no. xx: 531-51

The Ministry of Higher Education and Scientific Research-Jordan, (www.rce.mohe.gov.jo).

Thomas, S. (2012) "Ethics and accounting education", Issues in Accounting Education, vol. 2, no.2: 399-418

Thorne, L., Massey, D. \& Mangan, M. (2003) "Institutional context and auditors 'moral reasoning: A Canada-USA comparison", Journal of Business Ethics, vol. 43, no. 4: 305-321.

Top universities (2019), World University Rankings@ 2019. (www.topuniversities.com)

Trevino, L.K., Weaver, G.R., Gibson, D.G. \& Toffler, B.L. (1999) "Managing ethics and legal compliance: what works and what hurts", California Management Review, vol. 41 no. 2: 131-151

Titard, Pierre L., Robert L. \& Michael J. (2004) "Accounting education: response to corporate scandals. Helping the profession find opportunity in crisis," Journal of Accountancy, November, online version.

Tutara, H., Altınöz, M., \& Çakıroglu, D. (2011) "Is ethical leadership and strategic leadership a dilemma? A descriptive survey", 7th International Strategic Management Conference, 24 (2011) 1378-1388

Victor, B., \& Cullen, J. B. (1988) "The organizational bases of ethical work climates", Administrative Science Quarterly, vol. 33, no. 1: 101-125.

Watty, K., Sugahara, S., Abayadeera, N., Perera, L., \& McKay, J. (2014) "Towards a global model of accounting education", Accounting Research Journal, vol. 27, no. 3: 286-300

Yang, H. L., \& Wu., W. P. (2009) "The effect of moral intensity on ethical decision making in accounting", Journal of Moral Education, vol. 38, no. 3: $335-351$

Young, J. J., \& Annisette. M. (2009) "Cultivating imagination: Ethics, education and literature", Critical Perspectives on Accounting, vol. 20, no. 1: 93-109 